\title{
correspondence
}

\section{Plea for Argentinians}

SIR,-We are writing to call the attention of your readers to the harassment many of our colleagues in Argentina are undergoing at the present time.

The Junta Miltar headed by the general Jorge Videla has recently passed a law (ley de prescindibilidad, n.21.274) which allows to "release from duty" any employee of the public administration for unspecified "reasons of service", without further justification. This law has been the ground for expelling political dissenters from the universities and other scientific institutions, mainly in Buenos Aires and La Plata. The most affected institutions are, so far, the CONICET (Consejo Nacional de Investigaciones Cientificas y Technicas), the institutes depending on the Comision Nacional de Estudios Geoheliofisicos, and the Institudo Nacional de Tecnologia Agropecuaria. Not less than 550 persons have lost their jobs: biologists, physicists, chemists, medical doctors, architects, technicians and officers, some of them after 20 years, or more, of service.

On May 7 the newspaper La Opinion reported that the Representative on the Junta Militar in the Ministry of Education acting as State Secretary for Science and Technology had decided to "release" 90 employees. The newspaper quoted a few names of distinguished scientists. On Mav 12. in $\mathrm{La}$ Oninion, Horacio Encabo (viceDirector of the Centro de Investigaciones Neurologicas Torcuato Di Tella) expressed his worries in an article emphasising the risks for the develonment of Argentina of a scientific policy inspired by the criterion: "quien no es occidental y cristiano es subversivo" (who is not occidental and christian is subversive). Encabo was "released from duty" five days later.

Besides protesting against these vexations there are other ways of supporting this courageous political and moral stand of our colleagues: anyone can join us by writing to those he or she may know personally or by name: in forming them of his or her work bv sending reprints of preprints or renorts in fields of common interest: doing anything else to let them know that they are not left alone or forgotten by the world community of scientists to which they belong.

Yours faithfully,
F. Accascina, G. Olivieri, G. Tecce, G. ToschI (Rome);

G. G. Aloisi, G. Marino, U. Mazzucato, G. ReICHENBACH (Perugia);

R. Andreoli, L. Antolini, P. Barald, I. Baraldi, M. C. Bruni, L. Benedetti, P. G. De-Benedetti, R. Batistuzzi, S. Buffagni, I. M. Cramarossa, G, Faberi, A. Fabretti, G. Fini, G. Gavioli, A Guisti, G. Grandi, L. Menabue, P. Mirone, F. Momicchioli, G. Pellacani, A. Rastelli, E. Soragni, G. Tosi (Modena);

G. Bignami, A. Carpi, N. Frontali (Istituto Superiore Sanità, Roma);

L. Busetto, G. L. Bendanoli, P. BisCarini, M. Carlotti, G. Di Lonardo, G. Galloni, G. Nivellini, P. Palmieri, C. Stremmenos, F. Tullini, A. TromBETTI, C. ZAULI (Bologna);

R. Barbieri, M. Carapezza, G. Giudice, G. La Grutta, M. Leone, F. ODdo, U. M. Palma, M. B. Palma-Vittorelli, L. Paoloni, G. Serravalle (Palermo); E. Clementi, S. Pizzini (Istituto di Ricerche "G. Donegani" Novara);

S. Califano, E. Ferroni (Firenze);

G. Giacometti, E. Vianello (Padova);

G. Albanese, G. Casnati, R. Fieschi, M. Fontana, C. Giori, L. Oleari, E. SCRocco (Parma);

A. Monroy (Stazione Zoologica Napoli).

\section{Nuclear trade}

SIR,-As one who objects to all nuclear explosions, I would like to comment on "Heavy Water Allegations" (June 17, page 537). While I can understand Senator Ribicoff's concern about India misusing US-supplied heavy water, I personally feel that most of those who object to India's nuclear tests are hypocritical. How else does one explain the deafening silence that greeted the revelation that Israel had at least twenty bombs in the $20-30$ kiloton range? The critics of India's nuclear tests might well support Israel, using the well-worn argument that Israel is a perennially threatened state. But does any state's territorial integrity warrant a nuclear holocaust? I do not know if the US has aided Israel's nuclear programme, but I think it is reasonable to suppose that it did. If so, why does not Senator Ribicoff condemn Israeli nuclear tests?

The only way to save the world from nuclear destruction is to ensure that no country has a nuclear bomb. The present NPT cannot achieve this end because it is iniquitous. It assumes that the top five nuclear powers are the only ones which can be expected to behave responsibly. No self-respecting nation can tolerate this superpower arrogance. Those that have signed the NPT have done so under pressure. What we need today is a total elimination of nuclear arms. If this sounds naive and unattainable then, I assert, we have to be naive and we have to attain the unattainable if we want to prevent a world-wide Hiroshima.

The cynicism which characterises all super-power pronouncements on nuclear arms must give way to an enlightened idealism. The USA and the USSR should really be talking of Strategic Arms Elimination and not of Limitation. The West has provided enlightened leadership on several issues. Is it too much to expect it to collectively lead the world back to peace and sanity? You have produced both Bertrand Russell and Ronald Reagan. Is it unrealistic to expect that you would follow the former and not the latter?

$$
\begin{aligned}
& \text { Yours faithfully, } \\
& \text { C. S. G. PraSAD }
\end{aligned}
$$$$
\text { Macmillan Company of India Ltd., }
$$$$
\text { New Delhi } 110002
$$

\section{Genetic engineering}

SIR,-If, as Mr Norman reports, (July 1, page 2), the NIH did indeed recommend that, for safer recombination experiments, the recombinant DNA have "less than 1 in $10^{-8}$ chances of surviving in the natural environment", then the critics of such experiments should have even more qualms: one in $10^{-8}$ is equivalent to $100,000,000$ to 1 . Yours faithfully, Jerome G. Buescher

Department of Microbiology,

Thomas Jefferson University, Philadelphia, Pa.

\section{Human anatomy}

Srr,-We were interested to see Anthony Harris's measurements of asymmetry in young women (May 6, page 10 ) and the response of Connolly and Dangerfield (May 20, page 188), and have found our ratios right to left of ankle 1.006, calf 1.02, biceps 1.04, wrist 1.02 .

We conclude, assuming we are average females, that Anthony Harris's conclusions are correct and asymmetry is commonplace.

Yours faithfully,

Judy Whalley, Enin Thomas, Hilary Lane, Mary Brond, Gait, Weston, Sue Wit.kinson, Sandra Nixon, PENNY ELSIP

Department of Food Sciences,

Polytechnic of North London,

London, UK 